\title{
The vicious layering of multi-level governance in Southern Europe: the case of elderly care in Italy and Spain
}

\author{
Marco Arlotti ${ }^{1}$ and Manuel Aguilar-Hendrickson ${ }^{2}$
}

\begin{abstract}
Aging and changes in family arrangements and female employment have brought about important policy developments in long-term care. Southern European countries have relied for long on family care and residual social care for the dependent elderly. Two paradigmatic cases, Italy and Spain, have shown two apparently different trends during the last 15 years: while in Italy reforms seem to have been persistently blocked, in Spain, an ambitious reform has fallen short of expectations.

Based on data on services and institutional arrangements, the article shows that a complex and inconsistent allocation of responsibilities across government levels, a sort of "vicious layering" of multilevel governance, may be playing a key role in this situation. The article discusses the dysfunctional effects of such arrangements, namely territorial inequalities, cost-shifting between government levels and towards users and misallocation of resources.
\end{abstract}

We suggest that the development and reform of LTC in Southern European countries must address these problems if they want to avoid getting marooned by a complex network of vetoes and resource allocation problems.

\section{Keywords}

Long-term care, multi-level governance, vicious layering, Spain, Italy

\footnotetext{
${ }^{1}$ Politecnico di Milano, marlotti@polimi.it

${ }^{2}$ Escola de Treball Social, Universitat de Barcelona, manuel.aguilar.hendrickson@ub.edu
} 


\section{Introduction}

Over the last decades the ageing of population, and specially the growing number of people over 80 , has brought about a greater need of long-term care (LTC). This increase, together with changes in the labour market and in family arrangements, has shown the limits of traditional care arrangements and has put LTC high on the social policy reform agenda.

These trends are strong in Mediterranean countries such as Italy and Spain, which are paradigmatic examples of the Southern European welfare model (Ferrera 1996; Ranci \& Pavolini 2013). In these countries, LTC is mainly provided by intrafamily intergenerational solidarity. The public sector plays a residual role, often limited to people with low income and no family support, usually by means of cash benefits and fragmented local services. Only recently the market (formal for institutional care, often grey for home care) has begun to play a significant role. In both countries, families have made increasing recourse to the private care provided by migrant workers (Martínez-Buján 2009; Da Roit \& Sabatinelli 2012). This pattern may be called "unsupported familism” (Saraceno \& Keck 2010) or “passive subsidiarity” (Kazepov 2010).

Socio-demographic data on table 1 shows how the population over 80 has almost trebled in both countries since the mid-eighties, and its share of the population has more than doubled, growing faster than the EA18 average. During the same period, female employment rates, although still lower than the EA18 average, have grown very quickly, including for women aged 55 to 64 , which is specially affected by the care needs of their parents.

\section{TABLE 1}

Despite similar growing needs, over the last decade the institutional development of LTC in these two countries has followed different paths. In Italy, no structural reform of LTC policy has been undertaken (Costa 2013; Fargion 2013), whereas Spain introduced in 2006 a universal entitlement in the field of LTC for persons with reduced autonomy by passing the LAPAD 3 (Rodríguez Cabrero \& Marbán Gallego 2013; León \& Pavolini 2014). However, the implementation of this new scheme has been limited. The assessment of people in need has been slow, and while cash benefits (as opposed to in-kind services) were only foreseen for exceptional cases, in fact they have become widespread (Da 
Roit et al 2013; León \& Pavolini 2014).

In addition to the impact of the economic crisis and budgetary constraints, we suggest that the criticalities emerging in Italy and Spain regarding the development of LTC policy are also related to multilevel government arrangements in the fields of health and social care, and specifically to what we may term the "vicious" layering (Aguilar-Hendrickson, \& Sabatinelli 2014) of responsibilities in this policy field. The lack of clear coordination and efficient allocation of responsibilities and resources has stimulated blame avoidance and cost shifting strategies (Costa-Font 2010; Bonoli \& Champion 2014).

Section 2 of this article discusses multilevel governance and intergovernmental relations in the field of LTC from a theoretical point of view. Section 3 provides an overview of the main features of the governance of LTC in Italy and Spain. Finally, section 4 presents some of their main dysfunctional effects. The concluding section summarizes the main findings.

\section{Welfare States, multilevel governance and long-term care}

Throughout the history of modern welfare policies, the territorial dimension of its development has been relevant. Indeed, the development of welfare states was largely a process of centralization, moving from the basically local activities of poor relief and care of preindustrial societies to a growing role of regional and national programs (de Swaan 1988).

In recent years, however, welfare states have transformed their territorial organization. Social policies have been rescaled both upwards, with a new role of supra-national institutions, and downwards with an increasing role of regions and municipalities (Ferrera 2005; Kazepov 2010). This process, together with a multiplication of public and private stakeholders, has brought about a complex scenario of multilevel governance in the design, management and implementation of social policies (Kazepov 2010).

Evidence shows that the effects of decentralization and of multi-level governance can be ambivalent (Obinger et al 2005; Bonoli \& Champion 2014). On the one hand, the literature on welfare federalism has stressed negative consequences in terms of potential veto points, specially at the sub-national level. A federal welfare structure and a strong division of institutional responsibilities may discourage necessary reforms through cost-shifting between jurisdictions (Bonoli \& Champion 2014). Blame avoiding strategies may ease the implementation of retrenchment policies by dispersing the blame and 
shifting the responsibility for unpopular retrenchment policies to other levels of government (Ferrera 2005). Furthermore, the transfer of powers to sub-national level of government may also increase differences across territories, which can undermine a minimum standard of social citizenship in a national context (Kazepov 2010). However, these potential negative outcomes should not be taken for granted.

Decentralization and welfare federalism may, on the other hand, ease the development and endurance of social programs. Local and regional authorities tend to be closer to the population and may be more receptive to social demands, and they may also act as veto points to retrenchment proposals (Obinger et al 2005; Rauch 2006) and as reform catalysts in areas where both the perception of need and support for reform is widespread (Costa-Font 2010).

The way decentralized systems of governance are "layered" may be also crucial. Multilevel systems characterized by forms of "virtuous layering", in which a clear attribution of responsibilities and resources among the different territorial levels of government take place, can allow for both coordination and local adequacy, and minimize negative impacts. Conversely, negative impacts are more likely in countries characterized by a sort of "vicious layering", i.e., characterized by chaotic and not clearly framed inter-institutional relations (Aguilar-Hendrickson, \& Sabatinelli 2014).

Moving into the field of LTC, in many countries, as in Italy and Spain, it is divided between two policy fields, health and social care. Health care is usually more developed with stronger entitlements, whereas social care is often a residual and underfunded system of social protection, with weaker entitlements. Conflict between health and social care authorities is common in the provision and funding of LTC (Alber 1995; Lewis 2001; Ranci, \& Pavolini 2013) and integration of health and social care services has become a major issue in the field.

This cleavage is often compounded by the division of responsibilities between levels of government. Several studies have pointed out the relevance of multilevel governance and intergovernmental relations to understand changes in LTC policy. Campbell and Morgan (2005) have compared the evolution of old age care in Germany and the US. The introduction in Germany in 1994 of a new LTC social insurance program was stimulated by the concerns of German regions (Länder) about the growing 
burden of elderly care on sub-national social assistance schemes. German regions have an effective veto power on federal decision-making through the Bundesrat which helped them put pressure on the federal government to reform the system. Conversely, Campbell and Morgan explain the absence of a federal reform of LTC in the US by the fact that states have no ways to force the federal government to address their problems.

According to Morel (2006), the introduction in France in 1997 of a national social assistance benefit for LTC was pressed, like in Germany, by the sub-national levels of government (Départements) concerned about the growing number of elderly people which claimed a social aid benefit for disabled people managed and funded locally.

Rauch (2008) stresses the importance of intergovernmental relations when comparing changes in elderly care policies in Sweden and Denmark, countries with very decentralized systems. The autonomy of Swedish municipalities within a weak central regulation has allowed local retrenchment measures that explain the decrease in service coverage, in a context of budget crisis and a worsened demographic situation. In Denmark, a tighter central regulation of local autonomy has prevented this kind of process.

Institutional fragmentation is an important feature of LTC in Mediterranean countries (Costa-Font 2010). However, the effects of such fragmentation appear to work in different ways. In Spain, the introduction of a national reform for dependent elderly people in 2006 was supported by a coincidence of political interests at the central level (Marbán Gallego 2009). Although open vetoing is quite difficult in a sensitive field such as LTC, there is evidence of silent vetoing by some regional and local authorities. In Italy, instead, the fragmentation of interests has hindered any attempt to introduce a national reform in this policy field. The reform of the main LTC scheme, the Indennità di Accompagnamento (attendance allowance) has been hindered by the opposition of social stakeholders and the lack of regional pressure for reform, since their main concern is to preserve national funding via the health care budget. Gabriele and Tediosi (2014) point out that institutional fragmentation, increased by the 2001 constitutional reform, has hindered welfare innovations and reforms in Italy.

\section{Multilevel governance of LTC in Italy and Spain}

Italy and Spain are complex states with three main levels of government. Italy has 20 regions and 
Spain 17 "autonomous communities" with a significant degree of autonomy, plus a complex system of local authorities, which include municipalities and provinces, plus some other intermediate structures. ${ }^{4}$ This complex territorial organization affects LTC because responsibilities are divided across government levels and in different ways for each of its components.

Both countries have a clear differentiation between a mostly contributory and centralized pension and income maintenance system (which is the largest and most developed part of their social protection systems), a universal health care system and a residual and less developed set of means- and need-tested social services. Their old fragmented health insurance systems were reformed in the 1970s and 1980s into national universalistic care systems, centrally regulated but managed by regions. Much more limited reforms in social care have also taken place in both countries since the 1970s. The shift from residual "poor-relief" social assistance into a universalistic social care system is far from complete.

The role of the three main levels in the field of LTC may be summarized as shown in table 2 .

\section{TABLE 2}

In Italy, national and regional authorities share the regulation of health care services. The national government defined in 2001-20025 the basic levels of care for health care (livelli essenziali di assistenza, LEA), that include health care services for dependent elderly people.

The definition of the essential level for LTC is quite vague: no specific standards are set, such as coverage rate or user-to-practitioner ratios. It defines the share of costs covered by health services and the social care sector (including users' co-payment) run by municipalities. Health authorities must cover the costs of residential care for dependent people with high health needs (prestazioni sociosanitarie ad elevata integrazione sanitaria), while for people with less intense needs, municipalities and service users must bear half of the total cost. No earmarked financing for LTC has been defined within the yearly resources of the national health fund allocated by the central state to regions. Thus, the development of these services has been quite limited.

In social care, the main program in Italy is a cash benefit, the indennità di accompagnamento (attendance allowance). Although nationally regulated and funded, access to the benefit is managed by medical commissions belonging to regional health authorities. This scheme is not coordinated with 
either health or social care services. It is granted to all persons with total disability and unable to perform the basic activities of daily life without help. It is non means-tested, not taxable, beneficiaries may use it freely. It amounts to $512 €$ per month (2016), regardless of the degree of need. Introduced in the 1980s for disabled adults, it has gradually developed into a benefit for dependent elderly people. Some 2.2 million people were receiving the allowance in 2015.

Municipalities are responsible for the provision of social care services. Regulation is in the hands of regions, although the national government has set the basic level of services (livelli essenziali di assistenza sociale, LIVEAS). Such levels were defined in 2000, but somewhat vaguely and with no guaranteed funding.

In Spain regions are responsible for health care under a basic national framework. Management is fully in the hands of regions, which must fund it with their own budgets, although the national government contributes to that funding through the general regional funding system.

Nationally-defined health care includes the atención sociosanitaria as one of the basic services citizens are entitled to. Defined as the "simultaneous and synergic" action of health and social services, the health care system is only responsible for long-term health care, health care during convalescence and functional deficit rehabilitation. Although inclusion in the common health services portfolio should mean a strong entitlement, in practice its definition allows for a great freedom of interpretation. Regions are free to determine the provision level, and to establish the mechanisms to integrate the action of health and social services. The limit between long-term health and social care is also very blurry, and moving patients between them means changing from basically free health care to the much more limited and not completely free field of social care.

Pension supplements and attendance allowances are very limited, and belong in most cases to the pension system, which is the sole responsibility of the national government. Only one of these benefits, which is being phased out, is still managed by the regions but is regulated by central law. While the lack of a widespread cash benefit in Spain has been one of the factors that has eased in Spain (unlike in Italy) policy reform towards service expansion, the difficulties in the implementation of the LAPAD have somewhat paradoxically led to the development of a cash allowance to pay care by relatives. Conceived as an exceptional device for cases where no services were available, both the scarcity of 
services plus the level of co-payments have pushed a significant part (between one third and a half) of the recipients towards the cash allowance. The effects of this situation on the future development of services is yet to be seen.

Social services are the most fragmented component of LTC in Spain. The role of the national government in this field is, since the 2006 reform, similar to its role in health care: basic framework regulation and partial funding. Its funding role is slightly stronger than in health care, for there is a minimum (partial) national contribution for each protected person.

Unlike health care, however, regulation and management of social services, as well as their funding, is split between regional and local authorities (Rodríguez Cabrero et al 2011). In fact, these are more than two levels of government. Municipalities, "districts" which are unions of municipalities, either voluntary (mancomunidades) or compulsory in some regions (comarcas) and provinces are all local authorities, meaning that this layer is, in fact, made up of three layers. All three, plus regions, are legally expected to provide social services. Although in theory the higher levels should be a means to replace municipalities when they are too small, in fact they may be simultaneously providing the same or alternative services at the same place (Aguilar-Hendrickson 2013).

Responsibilities are not very clearly assigned among these levels. Regulation tends to attribute powers to act in the field rather than clear responsibilities. There are places where home help services may be provided both by local and regional governments, with each local authority establishing different access criteria and prices. In fact, home help services (as well as other residential and day care services) may be considered both as part of the LTC "system" or of "social services", depending on whether service users are entitled to care according to the national law or not. This adds to the confusion about available services and their funding.

\section{The dysfunctions of vicious layering}

We will now explore some of the problems that arise from governance dysfunctions in this policy field. Decentralization and multi-level governance of the LTC system into regional and local units need not be dysfunctional. It may help policies to be more adequate and closer to differing local preferences. But a decentralized system may result in fragmentation of responsibilities and territorial inequalities 
(Kazepov 2010) if it is not well designed. The division into different policy subfields, itself the result of the need for specialization, may develop into overlapping services or gaps between them, as well as into cost and blame-shifting (Bonoli, \& Champion 2014) if its components are not properly aligned. The lack of clearly defined entitlements may encourage shifting costs towards service users and their families, and the lack of a clear definition of responsibilities and duties may compound cost shifting with blame avoidance. Most of these factors may cause serious misallocation of resources.

The institutional arrangements of long term care governance in Spain and Italy fit into what we have termed as "vicious layering", that is, a multilevel governance arrangement whose design encourages the dysfunctions (gaps and overlaps, inefficiencies, blame and cost shifting and territorial inequalities) while it limits the benefits of decentralization. More specifically, the key elements of such an arrangement are: a) an imprecise definition of responsibilities (often defined as the power to do things rather than as specific duties); b) a separation between who faces certain social demands and is expected to "do something" about them and who collects and manages the resources needed for such a response; c) the lack of alignment between governance arrangements in the two policy fields involved (health and social care) in terms of who is in charge, who regulates them and how do people access services (entitlement or discretion, universal or means-tested, free or with co-payments).

\subsection{Territorial inequalities}

One of the most expected effects of decentralization is the territorial differentiation of services provision. By itself it shouldn't be a problem. In fact, the main reason for decentralization is the existence of local differences in needs, preferences, resources and opportunities that make different service provision a good idea. But such differences may evolve into inequalities.

Both Italy and Spain show very significant territorial differences in elderly care services. Tables 3 and 4 show regional differences in home and residential care coverage for each country. In Spain, home care coverage ranges from 1.9 to 9.5 per cent of people over 65 (with a national rate of 4.6). The same rate for residential services ranges between 2.2 and 7.5 per cent (excluding the very small city of Ceuta), with a national rate of 4.6. In Italy, the rate for social home care services is 1.3 per cent for the whole country, and it ranges between 5.3 per cent and values 0.3 per cent. Residential bed rates range between 4.4 and 0.6 per cent and the national average is 2.2 per cent. ${ }^{6}$ Moreover, data for Spain show that the actual contents of home care services may be very different. Regional differences in intensity 
range between 10 and 32 hours per month, and the share of personal care (without home cleaning) ranges between 90 and 15 per cent of the total service time. Local differences inside regions may be even bigger.

Table 3

Table 4

Regional differences may have several explanations. In Italy, there seems to be a clear relation between coverage rate and the North-South gradient, with some small outliers. Spain, on the contrary shows a much more complex pattern. Pino and Pavolini $(2015 ; 263-266)$ show that regional differences in welfare provision are more intense in Italy than in Spain, and that they seem to be more correlated to economic development in the former. In Spain, while some of the wealthier regions have high coverage rates (the Basque Country, Navarre or La Rioja), some don't (the Balearic Islands), and some of the poorer regions have higher coverage rates than some of the richer ones. In Spain there is no clear relationship between service coverage and female employment rates either.

Regional political preferences and priorities play a part. But although data is incomplete and more analysis is needed, it seems plausible that regional and local policy options that are not clearly connected to needs explain a significant part in regional differences in Spain (Martínez-Buján 2014). Some regions (Madrid, for instance) saw the implementation of the new LTC system as troublesome and conflicting with their previous arrangements, leading to significant delays in the development of the system (Barbieri \& Gallego 2016). The regional funding system, which is generally seen as problematic when not as openly dysfunctional (León Alfonso 2015), also plays a part in limiting the development of the system in some regions.

In both countries, available evidence suggests that the combination of loose national regulations with little or no national funding, and complicated regional and local arrangements for the definition of services and their funding are unable to guarantee comparable levels of LTC provision across regions. Moreover, such arrangements make shifting the blame for service inadequacy to other government levels very easy. 


\subsection{Cost shifting among governments}

The complex multilevel governance of the various LTC components has opened the way to develop cost shifting strategies between government levels and departments. Figure 1 tries to summarize the three main cost shifting strategies that per our hypothesis are crucial, within the multi-level governance of the LTC in Italy. These strategies are shifting costs from health care (regional) to the (national) attendance allowance, from health care (regional) to social care (local), and shifting costs to users. The first two , which shift costs to other levels or sectors of government, are discussed in section 4.2, the third, which shifts costs to families, is discussed in section 4.3.

Figure 1

In Italy, regions have handled the tension between increasing care demand and costs and budgetary constraints by "easing" access to the attendance allowance. The separation between who pays and who gives access and the lack of clear assessment criteria (Gori 2012), have created a perverse incentive to increase the number of beneficiaries, stimulated sometimes by clientelistic practices (Ascoli, \& Pavolini 2012). Therefore, regions have used the expansion of attendance allowance beneficiaries as a strategic lever to mitigate the financial pressure on health care put by growing LTC needs, shifting the cost to the central government.

A second mechanism of cost shifting adopted by the regions over the years is the shift of health costs to the social sector. The essential levels of health care state that regions (through the local health authorities) have a responsibility to implement and partly cover the cost of LTC services for dependent elderly people. However, the vagueness in the definition of these standards has allowed regions and local health authorities a wide margin of discretion.

In-depth regional case studies and recent court rulings show this process of shifting costs from health care to social care. For instance, in the region of Lombardy, the health care system is covering between 40 and 44 per cent of the costs in residential care, well below its legal obligation of covering 50 per cent (Guerrini 2011; Tidoli 2013). In another region, the Marche, the regional government set the essential levels for residential long-term care in the early 2000s at a total daily cost of 66 euros, and a 50-50 split between the health and the social care sectors (co-payment included). However, only 
approximately one third (in 2012) of those in need of LTC have received it (Ragaini 2013).

Several court rulings illustrate this process (Gioncada et al 2011). Among others, the regional administrative court (TAR) of Milan ruled in $2010^{7}$ that health care services were shifting their responsibility towards social care in cases of high care needs that should be entirely covered by the health care sector (prestazioni sociosanitarie ad elevata integrazione sanitaria). The court ruled the case of an elderly patient with a degenerative disease in coma whose needs were primarily healthcare needs (assisted feeding, catheter, treatment and prevention of decubitus). She had been for years in a residential care facility, and her relatives had covered entirely the costs, whereas, according to the law, the responsibility was of the health care sector. Similarly, in 2012 the Supreme Court ruled (no. 4558) that elderly people severely affected by Alzheimer's disease have predominantly healthcare needs. In this case, therefore, the health care sector must cover entirely the costs of residential care, given the high intensity of need. In this case as well, the relatives had for many years borne the costs of the elderly person's care in a local residential institution, whereas the responsibility was entirely of the health care sector.

In Spain, there is no exact equivalent of the attendance allowance responsibility split we find in Italy. However, as we have described before, there has been a similar shift towards in-cash family care benefits that are cheaper and easier to manage. Spain has similar problems of assigning responsibilities between health and social care. Nevertheless, the fact that the main funders of both fields are the regions seems to have limited strategies like the ones just mentioned for Italy. The main cost shifting problems seem to arise between the central government and regions in the field of social care. The development of the LAPAD foresaw a complex mechanism by which the central government would contribute with a minimum amount of money for every person assessed as dependent varying of the degree of need. This amount was to be made up of a fixed national minimum plus a second amount agreed with the regions, depending on their contribution. This system was later simplified, but tensions between central and regional governments about how to measure their respective contributions has led to numerous conflicts as official evaluation reports have shown (Cervera Macià et al 2009; Tribunal de Cuentas 2014). Harsh cost containment measures at the central level since 2012 have reduced the share of the cost borne by the central government and increased that of the regions 
(Montserrat Codorniu 2014).

In both countries, the development of these cost-shifting strategies is clearly connected to the lack of adequate and consistent definitions of responsibilities and duties, and to the split between who faces the problems and who has the resources to respond to them.

\subsection{Cost shifting towards service users}

In a context of cost containment and pressure to expand services, local (in Italy and Spain) and regional (in Spain) authorities responsible for social care have adopted an additional mechanism of cost-shifting, by increasing users' (or relatives') co-payment for services. Shifting costs to users is by no means limited to Mediterranean countries, and many countries have adopted this same strategy to cope with growing LTC needs in times of budgetary constraints (Ranci and Pavolini 2013). However, in Italy and Spain, the fragmented institutional framework regarding users' co-payment has stimulated this mechanism as well. The most affected field has been residential care, which in Italy is very relevant for local budgets (Fargion 2013).

In Italy, the national essential levels for residential care don't specify how the costs attributed to the social care sector must be divided between municipalities and dependent elderly people. The only clear element is the indicator for means-testing, the ISEE, ${ }^{8}$ which is family based. For people with disabilities and the dependent elderly the law has foreseen, instead, an individual means-test. After the devolution of responsibilities on social policies to regions in 2001 and the incomplete implementation of the law regarding the ISEE, municipalities have not adopted the ISEE for defining social costs for residential care. They have continued to consider not the "individual" economic condition, but that of the family as whole, requiring payment from relatives well beyond the nuclear family, i.e., not cohabitating adult children who according to the Italian Civil Code have a duty to provide support in case of need (Naldini 2003). Consequently, co-payment for residential care services has increased significantly, making it almost impossible for many families.

In Spain, the diversity of cost sharing arrangements in social care is even larger. Social services are split between regional and local authorities that may mean up to four different levels of government, depending of the area concerned. Each region has its own social services act, and responsibilities are not always clearly defined for each level of government. Although residential services tend to be regional, in 
many cases municipalities or provinces run them, and the opposite may be said for home care services.

Each of these hundreds of local and regional authorities may fix pricing and assessment and admission criteria.

The LAPAD was expected to introduce some order and clarity into this situation. It set relatively clear assessment procedures to determine who is dependent and who is not. On the other hand, it did not set clear criteria for co-payments, which must be regulated by regions, except for a generic clause that states that nobody should be deprived of care because of his or her economic situation. Until 2012 each region had its own system of setting co-payments. In 2012, under a strong pressure to reduce costs, all regions agreed to some common criteria. Although the criteria are common, in most cases they must be applied to a "service price" that is fixed by the concerned local authority. Such prices are not necessarily related to real costs. While the percentage of the cost is common for all regions and municipalities, the fixing of service prices allows for significant variations.

These criteria have put a very strong pressure on users, who are expected to cover a large share (up to 90 per cent of the cost) and are granted a very low level of exempt income (i.e., the amount of income that the person is entitled to keep), which was about 120 euros per month in 2014 (Montserrat Codorniu 2014).

The shift from a "family" to "a migrant in the family" care model in Italy (Naldini, \& Saraceno 2008; Da Roit, \& Sabatinelli 2012; Costa 2013) and in Spain (Martínez-Buján 2009), has acted as a safety valve as increasing care needs have been met with insufficient and fragmented service responses. Although the origins of such a model precede the reforms and the (limited) development of services, the important role of basically free to use cash allowances in both countries in easing such tensions has played into the hands of the migrant-in-the-family model.

\subsection{Misallocation of resources}

Data for Spain show some of the paradoxes and problems of a top-down universalizing reform of social care that must deal with the autonomy of a jungle of different government levels. The 2006 reform was formally the setting of some minimum standards to ensure that all citizens assessed as "dependent" in Spain has the same basic entitlement to care. It did not arrange nor organize the care 
system because it is in the hands of regions and local authorities. In fact, regions and local governments had been providing care for dependent people for years, just without any common criteria or standards and with no recognition of entitlements. The reform envisaged a process of "topping up" the existing services to cover not just a fraction of the dependent but all of them. The significant expansion of services in the previous years meant that the effort seemed possible.

If we look at the latest available figures (for 2012) on services for elderly people (IMSERSO 2014), we find some apparently paradoxical data. Out of 952 thousand claimants who had been assessed as dependent and entitled to care, 231 thousand were waiting for the allocation of services and 426 thousand were receiving the (supposedly exceptional) family care allowance. Some 295 thousand were being cared for by residential, day care or home care services. One might assume that such a large proportion of entitled dependent people not receiving services might be explained by the lack of enough care services, as it has been often argued.

Figure 2

Nevertheless, three quarters of public home care service recipients were non-dependent elderly people. While dependent entitled persons occupied 143,707 residential beds, another 241,753 were either being used by non-dependent persons or simply not occupied, 90,000 of which were either public of publicly funded. So, at the same time there was a lack of available services and a massive underuse of residential facilities and a widespread use of home help resources for less needed people.

Unoccupied beds in residential care facilities are difficult to measure. Official data are patchy but suggest that several thousand publicly funded residential beds might be unoccupied. Estimates using census data (Abellán 2013) suggest that about 20 per cent of all residential beds (70 to 80 thousand) may be unoccupied. Although no definite pattern seems to appear, surprisingly some of the regions with a higher vacancy rate (up to 40 per cent) are regions with low coverage rates.

In any case, these data strongly suggest there is a serious problem of resource misallocation. About home care services, local data and anecdotal evidence suggests that local authorities have for years been expanding home help as a low intensity service for people with light or no needs, leaving dependent people to be cared by families or in residential services (mostly in provincial and regional hands). Local political and management reasons may explain this policy orientation, paradoxical as it may seem for devoting scarce resources to those in less need. It's allows for a larger (albeit thinner) spread of services 
to more people, building a larger constituency. It is also easier to manage, since lighter care services are easier to organize along the whole day for different users.

The case of residential services is slightly different. The high price of some private services may explain part of the vacancies, as well as the construction of residences in places where needs were smaller than it was thought. Private for-profit residence misallocation may just be a bad business decision for which the investor should pay, although in some cases such decisions were encouraged by (equally unwise) incentives by local authorities, such as tax exemptions or free access to land.

Piecemeal information also shows that the public sector also built residential services with little demand. In some known cases, residential homes were built because of political pressure from small town local councils asking for regional funding to build local nursing homes, well above the expected demand (the minimum "reasonable" size for the homes was larger than the local demand). Some regions funded the construction of these services that were then left in the hands of local governments, with significant deficits. Once again, unclear definition of responsibilities, governments that are expected to do things that other governments must pay for in the end, and ad hoc bilateral agreements that are prone to clientelistic arrangements are a significant factor in the misallocation of resources.

Moreover, some of the cost containment measures such as high co-payments are dissuading people from using the services they need —and thus are kept unused. Further research is needed to fully measure and understand this problem.

As in Spain, in Italy the lack of a clear definition of institutional responsibilities in the field of LTC, and the vague definition of the basic levels of care, are developing into the misallocation of resources.

Table 5

Although the Italian residential care system varies from region to region, it includes residenze sociosanitarie, integrated health and social residential facilities with a high health care component which are the rough equivalent of nursing homes. Data on table 5 show that in Northern Italy, where residential care is more developed, the share of nursing homes is significantly higher. In 201388.9 per cent of elderly people (dependent or not) in residential care were in residenze socio-sanitarie in these regions. 
This means, on the one hand, that they receive a higher intensity of care (which is reasonable for dependent people), but on the other hand, it means that the centrality given to nursing homes in residential care has moved a significant number of non-dependent elderly people into these intensive care homes. More than half (55.4 per cent) of elderly people with no disabilities in residential care were in residenze socio-sanitarie in Northern Italy in 2013. The situation in Southern Italy is quite the opposite. Not only is residential care scarcer, but the supply of residenze socio-sanitarie is also more limited in relative terms. In 2013, 60.3 per cent of all elderly people in residential care were in nursing homes in the South. The fact that only 77.3 per cent of dependent elderly people in residential care are in nursing homes (far from the 92.7 per cent national average) suggests that about one fourth of the dependent elderly are in a type of residential care that is lighter than what they need. At the same time, almost a half of the non-dependent elderly people in residential care are in nursing homes in the South. All this suggests a combination of over-servicing of people with low needs (in most of the country) and under-servicing of people with high needs (specially in the South), in a context of overall insufficient supply of residential care.

\section{Conclusions}

In this article, we have analyzed, in a comparative perspective, the recent trends in long-term care for dependent elderly people in Italy and Spain. These are two countries where LTC needs are mainly covered by family and intergenerational solidarities. In-kind social services have been residual, while only recently the market has begun to play a significant role in both countries: families have made increasing recourse to the private care provided by migrant workers. The onset of the economic crisis has opened a process of retrenchment in both countries with negative impacts in terms of care arrangements for dependent elderly people.

The institutional development of LTC in these two countries has followed different paths. In Italy, no structural reform of LTC policy has been undertaken: a stagnant dynamic has affected in-kind services, while the coverage of the needs has been mainly delegated to an inertial expansion of the attendance allowance. Spain, on the other hand, expanded services and introduced in 2006 a national reform which established a formal universal entitlement to care services for dependent people.

However, the complex and unclear distribution of responsibilities in the field of social care services and its misalignment with the entitlement and governance model of health care has allowed for a series 
of vetoes, cost and blame shifting strategies and serious inefficiencies. The lack of a clear definition of responsibilities amongst the (numerous) institutional actors of LTC has a significant role in hindering reforms (in Italy) or in marooning them (in Spain). The reform in Spain set some basic national entitlements and standards but did not deal with the need for clearly allocating responsibilities and (enough) resources, which means "concentrating” responsibilities even in a decentralized model. It did acknowledge the need for health and social care coordination, but did not establish an aligned governance model that eased dealing with the "usual" problems of such coordination. Any reforms aimed at expanding LTC in a context of aging populations in these countries should address the problems posed by such institutional arrangements. 
Notes

1.

2

3 The Ley de Promoción de la Autonomía Personal y Atención a las personas en situación de dependencia, (Personal Autonomy Promotion and Care of Dependent People Act), commonly known in Spanish as ley de dependencia or LAPAD.

4 The designations of government levels may be somewhat confusing. In Spain, some regions use the term "national" for their institutions and the term "state" is often used to designate central institutions, which is the exact opposite of the naming convention in other countries. For the sake of simplicity, we shall use the terms "national" or "central" for country-wide institutions; "regional" for institutions of the Spanish "comunidades" (regardless of whether they consider themselves "nations", "nationalities” or "regions") and the Italian regions; and "local” for municipal and provincial institutions.

5 Decreto 29 novembre 2001 and Legge 289/2002, art. 54.

6 These data must be used with caution. They may not be fully homogeneous, and since most services are local, data is not always complete.

7 TAR ruling 1584/2010

8 Indicatore di situazione economica equivalente, or indicator of equivalent economic conditions. 
References

Abellán, A., 2013, Una de cada cinco plazas en residencias de mayores está vacante, Envejecimiento [enred].

Aguilar-Hendrickson, M., 2013, Retos de los servicios sociales, Presupuesto y Gasto Público, 71: 271-90.

Aguilar-Hendrickson, M. \& Sabatinelli, S. 2014, Changing Labor Markets and the Place of Local Policies, in C Ranci, T Brandsen \& S Sabatinelli (eds), Social Vulnerability in European Cities, Basingstoke-New York: Palgrave Macmillan, pp 67-102.

Alber, J., 1995, A framework for the comparative study of social services, Journal of European Social Policy, 5, 2: 131-49.

Ascoli, U. \& Pavolini, E., 2012, Ombre rosse. Il sistema de welfare italiano dopo venti anni di riforme, Stato e mercato, 3: 429-64.

Barbieri, N. \& Gallego, R. 2016, ¿Por qué se ha desplegado fe forma distinta la ley de Dependencia en Andalucía, Cataluña, Madrid y País Vasco entre 2007 y 2012? in R Gallego (ed),

Descentralización y desigualdad en el estado autonómico, Valencia: Tirant lo Blanch.

Bonoli, G. \& Champion, C., 2014, Federalism and Welfare to Work in Switzerland: The Development of Active Social Policies in a Fragmented Welfare State, Publius, 45, 1: 77-98.

Campbell, A.L. \& Morgan, K.J., 2005, Federalism and the Politics of Old-Age Care in Germany and the United States, Comparative Political Studies, 38, 8: 887-914.

Cervera Macià M, Herce San Miguel JA, López Casasnovas G, et al [Grupo de Expertos para realizar una evaluación del desarrollo y efectiva aplicación de la LAPAD] 2009, Informe final del Grupo de Expertos para la evaluación del desarrollo y efectiva aplicación de la Ley 39/2006 de 14 de diciembre de Promoción de la Autonomia Personal y Atención a las Personas en Situación de Dependencia, Madrid IMSERSO

(http://www.imsersomayores.csic.es/documentacion/biblioteca/registro.htm?id=53313)

Costa, G. 2013, Long-Term Care Italian Policies: A Case on Inertial Institutional Change, in C Ranci \& E Pavolini (eds), Reforms in long-term care policies in Europe: investigating institutional change and social impacts, Nueva York: Springer, pp 221-41.

Costa-Font, J., 2010, Devolution, Diversity and Welfare Reform: Long-term Care in the "Latin Rim", Social Policy and Administration, 44, 4: 481-94.

Da Roit, B. \& Sabatinelli, S., 2012, Nothing on the Move or Just Going Private? Understanding the Freeze on Child- and Eldercare Policies and the Development of Care Markets in Italy, Social Politics: International Studies in Gender, State \& Society.

Da Roit, B., González Ferrer, A. \& Moreno-Fuentes, F.J., 2013, The Southern European migrantbased care model, European Societies, 15, 4: 577-96.

Fargion, V. 2013, Le politiche per la non-autosufficienza, in V Fargion \& E Gualmini (eds), Tra l'incudine e il martello : regioni e nuovi rischi sociali in tempo di crisi, Bologna: Il Mulino, pp $37-71$.

Ferrera, M., 1996, The 'Southern model' of welfare in Social Europe, Journal of European Social Policy, 6, 1: 17-37.

Ferrera, M., 2005, The Boundaries of Welfare: European Integration and the New Spatial Politics of Social Protection, Oxford University Press.

Gabriele, S. \& Tediosi, F., 2014, Intergovernmental relations and Long Term Care reforms: lessons from the Italian case, Health policy (Amsterdam, Netherlands), 116, 1: 61-70.

Gioncada, M., Trebaschi, F. \& Mirri, P., 2011, Le rette nei servizi per persone con disabilità ed anziane. La compartecipazione al costo dei servizi residenziali, diurni e domiciliari, Maggioli: Santarcangelo di Romagna.

Gori, C., 2012, Home care in Italy: a system on the move, in the opposite direction to what we expect, Health \& Social Care in the Community, 20, 3: 255-64.

Guerrini, G. 2011, I servizi residenziali, in C Gori (ed), Come cambia il welfare lombardo. Una valutazione delle politiche regionali, Santarcangelo di Romagna: Maggioli, pp 217-44.

IMSERSO (Spain) 2014, Recursos sociales dirigidos a personas mayores en España. Datos a 31 de diciembre de 2012, Madrid, Ministerio de Sanidad, Servicios Sociales e Igualdad 
Kazepov, Y. (ed.), 2010, Rescaling social policies: towards multilevel governance in Europe, Ashgate, Farnham; Burlington, VT.

León Alfonso, S. (ed.), 2015, La financiación autonómica: claves para comprender un (interminable) debate, Alianza Editorial, Madrid.

León, M. \& Pavolini, E., 2014, 'Social Investment' or Back to 'Familism': The Impact of the Economic Crisis on Family and Care Policies in Italy and Spain, South European Society and Politics: $1-17$.

Lewis, J., 2001, Older people and the health-social care boundary in the UK: half a century of hidden policy conflict, Social Policy \& Administration, 35, 4: 343-59.

Marbán Gallego, V. 2009, Atención a la dependencia, in L Moreno Fernández (ed), Reformas de las politicas de bienestar en España, Madrid: Siglo XXI, pp 207-38.

Martínez-Buján, R., 2009, ¿Y qué pasa con mi cuidadora? Inmigración, servicio doméstico y privatización de los cuidados a las personas dependientes, Zerbitzuan, 45: 99-109.

Martínez-Buján, R., 2014, Los modelos territoriales de organización social del cuidado a personas mayores en los hogares / Regional Models of Social Organization of in-home Care for the Elderly, Revista Española de Investigaciones Sociológicas, 145: 99-126.

Montserrat Codorniu, J., 2014, El impacto de la crisis en el Sistema de Atención a la Dependencia, VII Informe sobre exclusión y desarrollo social en España. Documentos de Trabajo 5.6 (http://www.foessa2014.es/informe/uploaded/documentos_trabajo/23102014144847_4790. pdf) .

Morel, N. 2006, Providing coverage against new social risks in Bismarckian welfare states: the case of long-term care, in The politics of post-industrial welfare states, Routledge, pp 227-47.

Moreno Fuentes, F.J. 2009, Del sistema sanitario de la Seguridad social al Sistema nacional de Salud descentralizado, in L Moreno Fernández (ed), Reformas de las politicas de bienestar en España, Madrid: Siglo XXI, pp 101-35.

Naldini, M., 2003, The Family in the Mediterranean Welfare State, Frank Cass: London-Portland, Ore..

Naldini, M. \& Saraceno, C., 2008, Social and Family Policies in Italy: Not Totally Frozen but Far from Structural Reforms, Social Policy \& Administration, 42, 7: 733-48.

Obinger, H., Leibfried, S. \& Castles, F.G., 2005, Federalism and the welfare state : new world and European experiences, Cambridge University Press: Cambridge ; New York.

Pino, E. \& Pavolini, E., 2015, Decentralisation at the time of harsh austerity: multilevel governance and the welfare state in Spain and Italy facing the crisis, European Journal of Social Security, 17, 2: 246-70.

Ragaini, F., 2013, Residenze protette per anziani nelle Marche Posti convenzionati e rette a carico degli utenti Finalmente a disposizione i dati regionali, Marche. Osservatorio sulle politiche sociali,2013, http://www.grusol.it/vocesociale/05-02-13.PDF.

Ranci, C. \& Pavolini, E. (eds.), 2013, Reforms in long-term care policies in Europe: investigating institutional change and social impacts, Springer, Nueva York.

Rauch, D., 2006, Institutional fragmentation, institutional engineering and the development of elderly care and childcare in Sweden, Scandinavian political studies, 29, 4: 285-307.

Rauch, D., 2008, Central versus Local Service Regulation: Accounting for Diverging Old-age Care Developments in Sweden and Denmark, 1980-2000, Social Policy \& Administration, 42, 3 : 267-87.

Rodríguez Cabrero, G. \& Marbán Gallego, V. 2013, Long-Term Care in Spain: Between Family Care Tradition and the Public Recognition of Social Risk, in C Ranci \& E Pavolini (eds), Reforms in long-term care policies in Europe: investigating institutional change and social impacts, Nueva York: Springer.

Rodríguez Cabrero, G., Aguilar Hendrickson, M., Arriba González de Durana, A., Casas Mínguez, F., Laparra Navarro, M., Marbán Gallego, V. \& Pérez Eransus, B., 2011, Servicios sociales y cohesión social, Consejo Económico y Social: Madrid.

Saraceno, C. \& Keck, W., 2010, Can We Identify Intergenerational Policy Regimes in Europe? European Societies, 12, 5: 675-96.

de Swaan, A., 1988, In care of the state: health care, education, and welfare in Europe and the USA in the modern era, Polity Press-Blackwell: Cambridge-Oxford.

Tidoli, R., 2013, A che punto siamo sulla residenzialità per anziani? Tre Regioni a confronto con la 
Lombardia, LombardiaSociale.it,24 April 2013,

http://www.lombardiasociale.it/2013/04/24/a-che-punto-siamo-sulla-residenzialita-peranziani-tre-regioni-a-confronto-con-la-lombardia/.

Tribunal de Cuentas (Spain) 2014, Informe de fiscalización sobre las medidas de gestión y control adoptadas por las comunidades autónomas para la adecuada aplicación de la Ley 39/2006, de 14 de diciembre, de promoción de la autonomía personal y atención a las personas en situación de dependencia, Madrid, Tribunal de Cuentas 


\section{Tables and figures}

Table 1. Selected socio-economic indicators, Italy and Spain compared to the Euro-18 area

\subsection{Population over 80}

a) As a percentage of whole population

\begin{tabular}{lccc}
\hline & 1985 & 2000 & 2014 \\
\hline EA18 & 2,8 & 3,5 & 5,5 \\
Italy & 2,5 & 3,9 & 6,4 \\
Spain & 2,3 & 3,8 & 5,7 \\
\hline
\end{tabular}

b) Growth since 1985

\begin{tabular}{lccc}
\hline & 1985 & 2000 & 2014 \\
\hline EA18 & 100 & 134 & 222 \\
Spain & 100 & 168 & 296 \\
Italy & 100 & 160 & 278 \\
\hline
\end{tabular}

1.2. Female employment rate

a) Women $25-54$

\begin{tabular}{lcll}
\hline & 1985 & 2000 & 2014 \\
\hline EA18 & NA & 64,0 & 70,3 \\
Spain & 27,9 & 51,0 & 62,3 \\
Italy & 43,1 & 50,9 & 57,6 \\
\hline
\end{tabular}

b) Women 55-64

\begin{tabular}{lccc}
\hline & 1985 & 2000 & 2014 \\
\hline EA18 & NA & 24,2 & 45,6 \\
Spain & 18,9 & 20,1 & 37,8 \\
Italy & 14,8 & 15,3 & 36,6 \\
\hline
\end{tabular}

Source: own elaborations on Eurostat (tables demo_pjanind, demo_pjangroup,) and OECD data. 
Table 2. The allocation of institutional responsibilities in the field of elderly care: Italy and Spain

Care allowances* In-kind health care services In-kind social care services

Regulation Management Funding Regulation Management Funding Regulation Management Funding

\begin{tabular}{|c|c|c|c|c|c|c|c|c|c|}
\hline \multicolumn{10}{|l|}{ Italy } \\
\hline State & +++ & +++ & +++ & $+++(-)$ & & +++ & $+(-)$ & & + \\
\hline Regions & & ++ & & +++ & +++ & + & +++ & & + \\
\hline Municipalities & & & & & & & & +++ & +++ \\
\hline \multicolumn{10}{|l|}{ Spain } \\
\hline State & +++ & +++ & +++ & + & & + & + & & + \\
\hline Regions & & + & & +++ & +++ & +++ & +++ & +++ & +++ \\
\hline Municipalities & & & & & & & ++ & +++ & ++ \\
\hline
\end{tabular}

$\mathrm{R}=$ regulation $; \mathrm{M}=$ management $\mathrm{F}=$ funding .

Degree of responsibility: +++ = very high; ++ = high; + = low; $(-)=$ weakened responsibility; blank = absent.

* In Italy, the attendance allowance. In Spain includes only pension supplements and old attendance allowances which are very limited. Family care allowances as part of the LAPAD system are included in in-kind services.

Source: own elaborations. 
Table 3. Ratio of social home care users and residential beds for the elderly to population over 65 by autonomous community in Spain (2012)

Social home care users

\begin{tabular}{lll}
\hline Andalucía & 4.36 & 3.23 \\
Aragón & 4.62 & 6.36 \\
Asturias & 4.49 & 5.96 \\
Balears (IIles) & 2.61 & 2.39 \\
Canarias & 3.54 & 2.94 \\
Cantabria & 3.48 & 4.98 \\
Castilla-La Mancha & 4.76 & 7.36 \\
Castilla y León & 5.82 & 7.47 \\
Cataluña & 4.45 & 5.00 \\
C Valenciana & 1.92 & 2.97 \\
Extremadura & 5.53 & 6.11 \\
Galicia & 2.89 & 3.65 \\
Madrid & 9.50 & 4.94 \\
Murcia & 2.41 & 2.21 \\
Navarra & 5.51 & 5.65 \\
País Vasco & $2.43^{*}$ & 5.96 \\
Rioja & 5.91 & 5.05 \\
Ceuta & 7.72 & 1.85 \\
Melilla & 6.19 & 4.00 \\
\hline SPAIN & 4.61 & 4.62 \\
\hline
\end{tabular}

* Data for 2013

Source: IMSERSO 
Table 4. Ratio of social home care users and residential beds for the elderly to population over 65 by regions in Italy (2012)

Social home care users

Residential beds

\begin{tabular}{lll}
\hline Piemonte & 0.8 & 3.9 \\
Valle d'Aosta & 5.3 & 3.9 \\
Liguria & 1.1 & 2.9 \\
Lombardia & 1.4 & 3.0 \\
Trentino & 4.3 & 4.4 \\
Veneto & 1.4 & 3.1 \\
Friuli-Venezia Giulia & 2.3 & 3.5 \\
Emilia-Romagna & 1.4 & 3.3 \\
Toscana & 0.7 & 1.7 \\
Umbria & 0.3 & 1.3 \\
Marche & 0.7 & 2.1 \\
Lazio & 0.9 & 1.2 \\
Abruzzo & 1.3 & 1.5 \\
Molise & 2.0 & 1.8 \\
Campania & 1.1 & 0.6 \\
Puglia & 0.7 & 1.0 \\
Basilicata & 1.3 & 1.3 \\
Calabria & 1.0 & 0.8 \\
Sicilia & 1.7 & 1.1 \\
Sardegna & 2.5 & 1.3 \\
ITALY & 1.3 & 2.2 \\
\hline
\end{tabular}

Source: Istat (b); (c). 
Table 5. Share of service users in residenze socio-sanitarie over the total number of residential care users per category. Italy 2013

\begin{tabular}{lcccc} 
& North & Center & South & Italy \\
\hline All elderly persons & 88,9 & 70,4 & 60,3 & 81,7 \\
Non-dependent elderly persons & 55,4 & 38,3 & 41,1 & 47,5 \\
Dependent elderly persons & 95,7 & 88,4 & 77,3 & 92,7 \\
\hline
\end{tabular}

Source: own elaborations on Istat (2015). 
28

Figure 1. Vicious layering, cost shifting and care privatization of LTC for dependent elderly people in Italy 


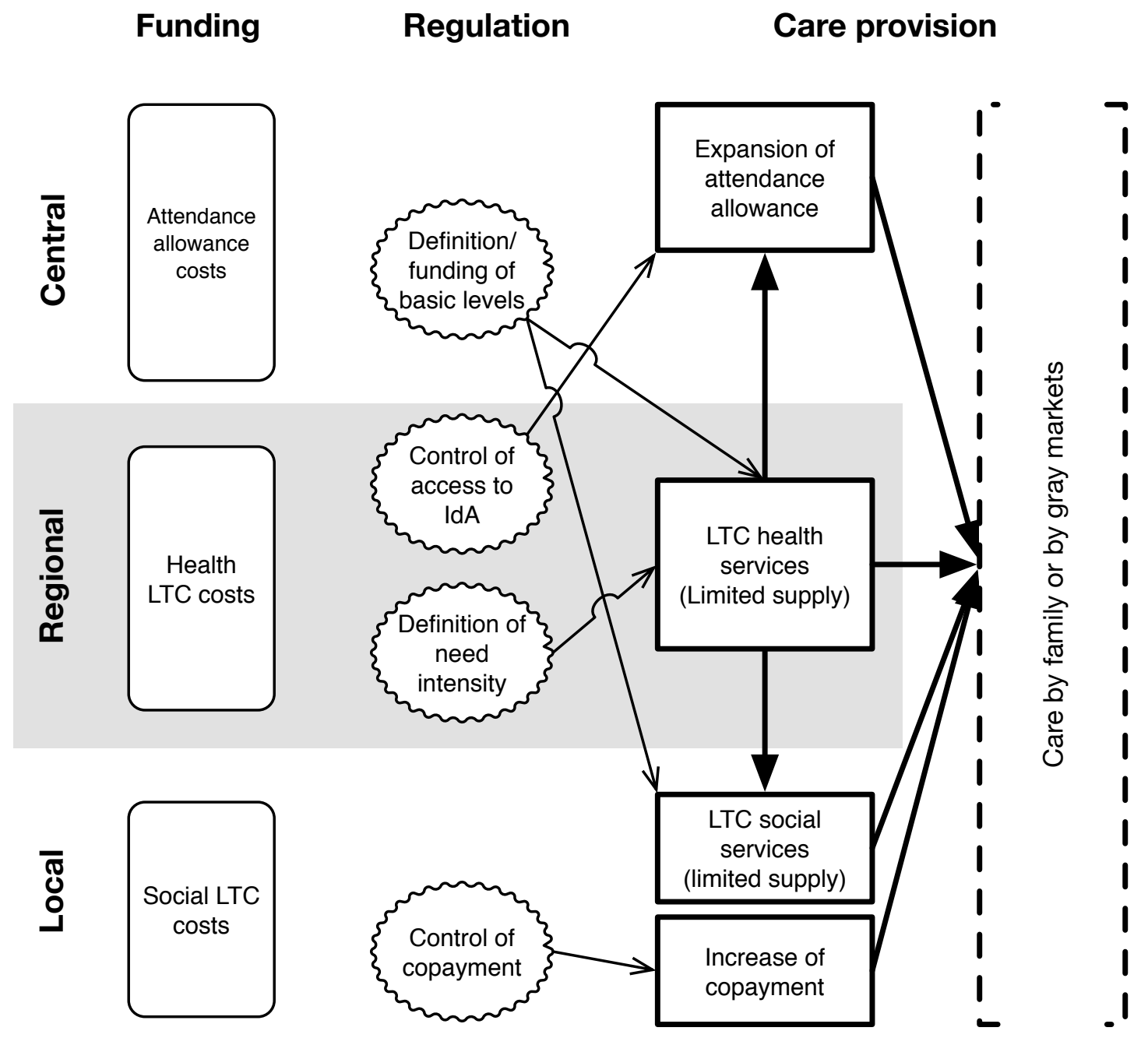


Figure 2. Dependent and non-dependent elderly people cared for by social services in Spain 2012

Source: IMSERSO and SISAAD 
Residential care
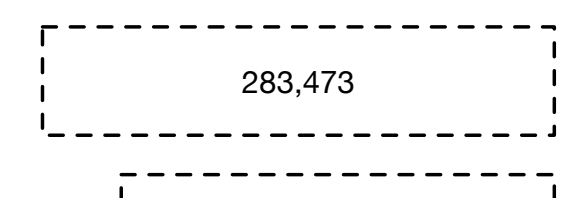

Day care

Family attendance allowance

No services nor benefits
Used by others/ not used

Dependent persons

(entitled according to the law)

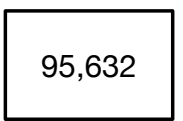

143,707

241,753

$31,294 \begin{array}{rr}1 & 1 \\ 1 & 1 \\ 1 & -1\end{array}$

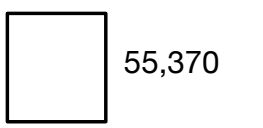

\section{6,810}

